\title{
The effect of antenatal depression and antidepressant treatment on placental tissue: a protein-validated gene expression study
}

Åsa Edvinsson ${ }^{1 *} \mathbb{B}$, Charlotte Hellgren', Theodora Kunovac Kallak', Helena Åkerud², Alkistis Skalkidou', Elisabet Stener-Victorin ${ }^{3}$, Romina Fornes ${ }^{3}$, Olav Spigset ${ }^{4,5}$, Susanne Lager ${ }^{1}$, Jocelien Olivier ${ }^{6+}$ and Inger Sundström-Poromaa ${ }^{1 \dagger}$

\begin{abstract}
Background: Antenatal depression affects $10-20 \%$ of pregnant women. Around 2-4\% of European pregnant women use antidepressant treatment, most commonly selective serotonin reuptake inhibitors (SSRIs). Poor pregnancy outcomes, such as preterm birth and low birth weight, have been described in women with antenatal depression and in pregnant women on SSRI treatment. However, the effects of antenatal depression and antidepressant treatment on the placenta are largely unknown. The aim of this work was to compare placental gene and protein expression in healthy women, women with untreated antenatal depression and women on antidepressant treatment during pregnancy.

Methods: Placental samples from 47 controls, 25 depressed and 45 SSRI-treated women were analysed by means of qPCR using custom-designed TaqMan low-density arrays (TLDAs) for 44 genes previously known to be involved in the pathophysiology of depression, and expressed in the placenta. Moreover, placental protein expression was determined by means of immunohistochemistry in 37 healthy controls, 13 women with untreated depression and 21 women on antidepressant treatment. Statistical comparisons between groups were performed by one-way ANOVA or the KruskalWallis test.

Results: Nominally significant findings were noted for HTR1A and NPY2R, where women with untreated depression displayed higher gene expression than healthy controls $(p<0.05)$, whereas women on antidepressant treatment had similar expression as healthy controls. The protein expression analyses revealed higher expression of HTR1A in placentas from women on antidepressant treatment, than in placentas from healthy controls $(p<0.05)$.

Conclusion: The differentially expressed HTR1A, both at the gene and the protein level that was revealed in this study, suggests the involvement of HTR1A in the effect of antenatal depression on biological mechanisms in the placenta. More research is needed to elucidate the role of depression and antidepressant treatment on the placenta, and, further, the effect on the fetus.
\end{abstract}

Keywords: Antenatal depression, Antidepressant treatment, Selective serotonin reuptake inhibitors, Placental gene expression, TaqMan low-density array, Placental protein expression, Immunohistochemistry

\footnotetext{
* Correspondence: asa.edvinsson@igp.uu.se

Jocelien Olivier and Inger Sundström-Poromaa are co shared last authors.

'Department of Women's and Children's Health, Uppsala University, 75185

Uppsala, Sweden

Full list of author information is available at the end of the article
}

(c) The Author(s). 2019 Open Access This article is distributed under the terms of the Creative Commons Attribution 4.0 International License (http://creativecommons.org/licenses/by/4.0/), which permits unrestricted use, distribution, and reproduction in any medium, provided you give appropriate credit to the original author(s) and the source, provide a link to the Creative Commons license, and indicate if changes were made. The Creative Commons Public Domain Dedication waiver (http://creativecommons.org/publicdomain/zero/1.0/) applies to the data made available in this article, unless otherwise stated. 


\section{Introduction}

During pregnancy a woman's body undergoes numerous changes, both physically and mentally. The overall risk of experiencing depressive symptoms during this time period is as common as in the population as a whole, approximately $10-20 \%[1,2]$, whereas major depressive disorder is found in around $4-7 \%$ of pregnant women [3-6]. Suffering from depression in pregnancy could have serious consequences for both the mother and the child. Almost $11 \%$ of women of childbearing age in Sweden were using antidepressant medication in 2016 [7]. The most commonly prescribed antidepressants in pregnancy are selective serotonin reuptake inhibitors (SSRIs), with a prevalence of around $2-4 \%$ in pregnant women in Europe, and $4-10 \%$ in North America [8-12]. Poor pregnancy outcomes, such as preterm birth and low birth weight have been reported both in women with antenatal depression and in women who used antidepressant treatment during pregnancy, and it is presently unclear whether it is the SSRI treatment or the depression itself that causes these complications [13-15].

The placenta is a transitory organ that connects the fetus to the mother and acts as a bridge between the maternal and the fetal circulations. The fetal part of the placenta consists of chorionic villous trees that contain a variable amount of fetal vessels and stroma covered by a cytotrophoblast and a syncytiotrophoblast layer. Maternal blood pools into the intervillous space and bathes the villous trees, where feto-maternal exchange takes place [16]. Anchoring villi are attached to the maternal part of the placental tissue, the decidua basalis, which is developed from uterine tissue. Placental dysfunction can have devastating consequences for both the mother and the child. Fetal growth can be negatively affected if the placental blood supply is insufficient or if the transport of oxygen and nutrients is affected, which can lead to low birth weight, preterm birth, and birth defects [17-19]. Moreover, the mother is at increased risk of developing conditions such as pre-eclampsia as a result of placental dysfunction, and a history of pre-eclampsia is also associated with abnormalities in the placenta in the current pregnancy [20].

SSRIs have the ability to cross the placenta and have been found in both cord blood and amniotic fluid [21, 22]. Serotonin is involved in embryogenesis [23], placentation [24], and placental vasoconstriction [25], all of which may affect the fetus. In mice, maternal SSRI treatment has been shown to alter multidrug resistance (phosphoglycoprotein) activity both in the placenta and in the fetal and maternal blood-brain barrier, resulting in altered drug transfer into the fetal and maternal brain [26]. Another study in mice revealed a placental serotonin synthetic pathway [27], where serotonin produced in the placenta accumulates in the fetal forebrain during the developmental phase that corresponds to the first and second trimester in humans. This phase includes cortical neurogenesis, migration and initial axon targeting, which are crucial mechanisms for normal neurodevelopment [27].

Regarding the effect of maternal mental illness on placental function, several studies within a review by Gentile and Fusco describe altered gene/protein expression and epigenetic modifications in placenta from depressed mother with or without antidepressant treatment [28]. In addition, studies carried out by our research group have revealed altered gene expression in the fetal part of the placenta in women with depression during pregnancy compared with non-depressed pregnant women $[29,30]$. Moreover, use of SSRIs during pregnancy has been found to alter placental gene expression in the fetal part compared with placental gene expression in healthy pregnancy $[29,30]$. Oxytocin has an important endocrine role in pregnancy and parturition and methylation of the oxytocin receptor (OXTR) has been linked to mental disorders $[31,32]$. Of interest is a study by Galbally et al. suggesting that antidepressant exposure rather than depressive symptoms during pregnancy can alter OXTR methylation in placental tissue [33]. Also, decreased expression of the imprinted gene PEG3 in the placenta have been found associated with maternal depression [34]. Investigators have also described genes involved in the hypothalamic-pituitary-adrenal (HPA) axis that are differentially expressed in placentas from mothers suffering from prenatal stress compared with healthy mothers [35-39]. There are also studies describing associations between maternal depression, the placenta and child behaviour and temperament [40, 41]. However, much remains to be revealed concerning the biological effects of fetal exposure to maternal depression and its treatment. Specifically, more research is needed to elucidate the different effects of antenatal depression and antidepressant treatment on placental function and the offspring. The aim of this work was to compare placental gene and protein expression in healthy women, women with antenatal depression and women on antidepressant treatment during pregnancy. For this purpose, we selected genes that have previously been shown to be involved in mood disorders, and at the same time known to be expressed in the placenta.

\section{Materials and methods}

\section{Study population}

The placental samples for this study were derived from the Biology, Affect, Stress, Imaging, Cognition (BASIC) project, which is a population-based, longitudinal study on psychological well-being during pregnancy and the postpartum period, conducted at the Department of 
Obstetrics and Gynaecology, Uppsala University Hospital. In the BASIC study all women attending routine ultrasound examination at gestational weeks $16-18$ are invited to participate. Exclusion criteria in the BASIC project are (1) inability to communicate adequately in Swedish, (2) protected identity, (3) age less than 18 years, and (4) blood-borne infectious diseases. In Uppsala, all routine ultrasound examinations are performed at Uppsala University Hospital and $97 \%$ of pregnant women participate. Moreover, the only delivery ward in the county is at Uppsala University Hospital, thus forming the basis of a population-derived sample. Written informed consent is obtained from women who choose to participate in the BASIC project, and within this consent document women also specify whether or not blood and placental samples may be collected at delivery. Placental tissue was collected between April 2010 and September 2013, and in all, 957 placental samples were collected.

In the BASIC project, women are followed by means of web-based questionnaires at gestational weeks 17 and 32. At both of these times women fill out the Edinburgh Postnatal Depression Scale (EPDS) [42, 43], together with detailed information on previous and ongoing medical treatment, including antidepressant use, smoking, educational level and country of origin. Information on maternal body mass index (BMI) (gestational weeks 1012 ), obstetric and perinatal variables is retrieved from the medical records.

The EPDS is a self-administered instrument that contains 10 statements, scored from zero to three, rendering a maximum score of 30 . This instrument does not provide a diagnosis of depression as such, but a higher total score increases the likelihood of having a major depressive episode. EPDS statements are based on the past seven days. The sensitivity is relatively low, but the scale has a specificity of $98-99 \%$ for major depression at a cut-off score of $>12$ points during pregnancy [44]. The internal consistency and test-retest reliability of the EPDS questionnaires had a Cronbach's alpha of 0.88 , and a coefficient of stability of 0.77 .

A selection of the women in the BASIC cohort also participated in a psychophysiological sub-study in late pregnancy and early postpartum. As part of this substudy, women were subjected to a psychiatric interview, the Mini International Neuropsychiatric Interview (MINI), by which a diagnosis of minor or major depressive disorder was established. Blood samples were also drawn at these visits.

For this study, placental samples from 47 healthy controls, 25 women with untreated antenatal depression and 45 women on antidepressant treatment were used. General exclusion criteria for all groups were maternal age > 42 years, alcohol use during pregnancy, any pregnancy complication that would influence, or be a sign of, compromised placental function such as pre-eclampsia, gestational diabetes, pre-pregnancy diabetes, intrauterine growth restriction, offspring born small for gestational age, and gestational age $<35$ weeks at delivery.

The definition of being depressed in this study was a diagnosis of depression according to the MINI interview ( $n=19)$, or an EPDS score of $\geq 12$ in weeks 17 and 32 , together with a diagnosis of previous major depression according to MINI or according to medical records $(n=6)$. According to the medical records women on antidepressants used their treatment during at least half of the pregnancy in clinically relevant doses. The control subjects had a maximum EPDS score of 11, and no on-going/earlier psychiatric disease according to medical records, and were matched to the depressed and SSRI-treated women with respect to BMI $( \pm 2.0 \mathrm{~kg} /$ $\left.\mathrm{m}^{2}\right)$ and age ( \pm 5 years).

\section{Samples}

The BASIC placental tissue samples were collected and processed directly after delivery. Two basal-plate biopsy samples from the maternal-fetal interface, of approximately one $\mathrm{cm}$ in thickness, were excised from the central part of the placenta containing both the maternal decidua basalis and fetal villous tissue. Calcified areas or infarcts in the tissue were avoided. The tissue samples were carefully rinsed with sterile phosphate-buffered saline (PBS) and put on dry ice within $30 \mathrm{~min}$ after delivery. The samples were stored at $-70^{\circ} \mathrm{C}$ until further processing. For paraffin-embedded placental samples, tissues were fixed for $24 \mathrm{~h}$ in $4 \%$ formalin, and stored in $70 \%$ ethanol until paraffin-embedding.

A placental sample of $3 \mathrm{~mm}^{3}$ was taken from the fetal side of the frozen placental tissue piece for isolation of total RNA using RNeasy mini kits (\#74106, Qiagen, Hilden, Germany). The tissue was homogenized and lysed using a rotor-stator homogenizer and RLT- $\beta$-mercaptoethanol, according to the manufacturer's protocol. The amount and quality of RNA were determined by using NanoDrop technology and by Agilent RNA 6000 Nano assays, respectively (Dalcochromtech, Life Technologies Inc., CA, USA).

Single-strand cDNA was synthesized from $250 \mathrm{ng}$ of total RNA using Superscript VILO MasterMix kits (Life Technologies, Paisley, UK), following the manufacturer's protocol, resulting in a total amount of $250 \mathrm{ng} \mathrm{cDNA} /$ sample.

\section{Low-density Array analysis}

Quantitative real-time PCRs were run with customdesigned TaqMan low-density arrays (TLDAs) (Applied Biosystems, Foster city, CA, USA) for 44 genes previously known to be involved in the pathophysiology of depression, and expressed in the placenta 
(Additional file 1). These genes represent: i) monoaminergic pathways, including genes such as sodiumdependent serotonin transporter (SLC6A4), aromatic 1amino acid decarboxylase $(A A D C)$, and monoamine oxidase $\mathrm{A}(M A O A)$, all involved in monoamine transport to the fetus [27, 45]; ii) hypothalamic-pituitary-adrenal (HPA) axis function, including genes such as corticotrophin-releasing hormone $(C R H)$ and neuropeptide $\mathrm{Y}(N P Y)$, which drive the maternal HPA axis during pregnancy [46], and $11 \beta$ hydroxysteroid dehydrogenase types 1 and 2 (HSD11B1 and 2), responsible for shuttling of cortisol to the fetus [47]; iii) other hormonal systems, including oxytocin $(O X T)$ and enzymes involved in progesterone metabolism, such as $5 \alpha$-reductase types I and II (SRD5A1 and 2) and 3 $\alpha$-hydroxysteroid dehydrogenase (AKR1C4) [48, 49]; iv) growth factors, including vascular endothelial growth factor (VEGF) and brainderived neurotrophic factor (BDNF), and v) genes involved in placental drug metabolism and transport. Finally, we included nerve growth factor $(N G F)$ to validate our previous findings [29, 30]. Four genes, GAPDH, TOP1, YWHAZ, and $A B C B 1$ were included in the arrays as reference genes (Additional file 1).

Each TaqMan LDA consisted of 384 wells and 8 ports (48 wells/assays per port). The 117 samples were loaded to the TLDAs via the ports, one sample per port, which resulted in 15 TLDAs in total. Samples were run as singletons, and the amount of cDNA in each loading port was equivalent to $100 \mathrm{ng}$ of mRNA. The arrays were run according to the manufacturer's protocol with an ABI Prism 7900HT Sequence Detection System and ABI Prism 7900HT SDS software version 2.4 (Applied Biosystems).

Each assay included a forward primer, a reverse primer, and a TaqMan ${ }^{\circ}$ MGB probe (Additional file 1) with the reporter $\mathrm{FAM}^{\mathrm{Tm}}$ and the quencher MGB-NFQ. Negative controls consisted of no template (water).

Each placental sample (100 ng cDNA) was diluted with sterile water to a volume of $50 \mu \mathrm{L}$, with addition of an equal volume of TaqMan Universal PCR Master Mix ( $2 \times$; Applied Biosystems). The sample was loaded to the TaqMan LDA, which was then centrifuged twice for 1 $\mathrm{min}$ at $331 \times g$. In cases of excess sample in the fill reservoir the LDAs were spun for an additional $1 \mathrm{~min}$. The final volume in each well after centrifugation was $1.5 \mu \mathrm{L}$, which yielded $1.5 \mathrm{ng}$ cDNA per reaction. Real-time RTPCRs were run with thermal cycling conditions of $2 \mathrm{~min}$ at $50{ }^{\circ} \mathrm{C}, 10 \mathrm{~min}$ at $95{ }^{\circ} \mathrm{C}$, followed by 40 cycles of denaturation at $95^{\circ} \mathrm{C}$ for $15 \mathrm{~s}$ and annealing and extension at $60{ }^{\circ} \mathrm{C}$ for $1 \mathrm{~min}$.

\section{Analysis of real-time RT-PCR data}

Manual confirmation of threshold detection was conducted for quality-control purposes. We utilized Ct number as input for our variability analysis among tissue samples for each target. Results for each target in TLDA analysis were quantified concurrently using the same baseline and threshold for a target gene in order to limit inter-plate errors in the analysis. By using NormFinder, GeNorm algorithms and GenEx software (MultiD Analyses) [50], we identified GAPDH and YWHAZ as the most stable combination of genes to use for normalization in data analysis. Normalization of the data included subtraction of the mean $\mathrm{Ct}$ values of the best combination of housekeeping genes from the mean $\mathrm{Ct}$ value for each gene in each group $(\Delta \mathrm{Ct})$. A higher $\Delta \mathrm{Ct}$ value refers to a lower gene expression, and a lower $\Delta \mathrm{Ct}$ value refers to a higher gene expression respectively.

\section{Immunohistochemistry}

Based on availability of paraffin-embedded blocks of placental tissue among women included in the geneexpression analysis, placental-protein expression was determined in 37 healthy controls, 13 women with untreated depression and 21 women on antidepressant treatment. The paraffin-embedded blocks were sectioned $(4 \mu \mathrm{m})$ and the samples placed on Superfrost slides. The slides were processed according to a standardized immunohistochemistry protocol, with antibody retrieval in $1 \times$ citrate buffer for $10 \mathrm{~min}$ in a 650 $\mathrm{W}$ microwave oven. An endogenous peroxide-blocking step for $10 \mathrm{~min}$ in $3 \% \mathrm{H}_{2} \mathrm{O}_{2}$ in ethanol was followed by a non-immune block with $5 \%$ normal goat/horse serum in $0.1 \%$ bovine serum albumin (BSA) in PBS for one hour at room temperature (RT).

The primary antibodies used in the following step were anti-HTR1A (PA5-28090, rabbit, Thermo Fisher Scientific) and anti-NPY2R (PA1-41576, rabbit, Thermo Fisher Scientific), at dilutions of 1:500 and 1:250, respectively. The antibodies were applied to the slides, which were then kept at $5{ }^{\circ} \mathrm{C}$ overnight. As a negative control we used $0.1 \%$ BSA in PBS. After the primary antibody step a secondary antibody was applied to the tissue sections for one hour at RT at a dilution of 1:300 in $0.1 \%$ BSA in PBS. The secondary antibody used in this study was a biotinylated Goat Anti-Rabbit antibody (Vector labs BA-1000). As a detection method we used a colorimetric system including an enzyme, horseradish peroxidase (HRP) (dilution 1:400, $1 \mathrm{~h}$ at RT, Vector labs A-2004), and a substrate, DAB (3,3'-diaminobenzidine) (dilution, chromogen/substrate 1:50, $20 \mathrm{~s}$ at RT) (Dako). The enzyme HRP catalyses oxidation of the substrate $\mathrm{DAB}$, resulting in a brown colour in the sample. Mayer's haematoxylin was applied for staining of the cell nuclei.

\section{Immunohistochemical scoring}

The immunohistochemically stained placental-tissue sections were analysed in terms of staining pattern, distribution, intensity (0-3), and the proportion (\%) of stained 
cells. Two independent scorers carried out the scoring in a blinded manner as regards case/control status. Intensity was defined as negative (0), weak (1), medium (2), or strong (3). The tissue samples were further evaluated by calculating an $\mathrm{H}$-score (histo-score), based on the staining intensity and proportion of stained cells. The $\mathrm{H}$-score takes into account different staining intensities within the same tissue sample, and is assigned using the following formula: $[1 \times(\%$ of cells with intensity score 1$)+2 \times(\%$ of cells with intensity score 2$)+$ $3 \times(\%$ of cells with intensity score 3$)]$. The final score thus ranges from 0 to $300[51,52]$.

\section{Antidepressant concentration measurement}

Maternal blood for the analysis of antidepressant serum concentrations was obtained at the delivery ward prior to the woman's delivery. Blood samples were centrifuged at $1500 \mathrm{RCF}$ for $10 \mathrm{~min}$ and the sera were stored at $70^{\circ} \mathrm{C}$ within $1 \mathrm{~h}$ of delivery.

Citalopram, escitalopram, sertraline, and fluoxetine and its active metabolite norfluoxetine were analysed using liquid chromatography-mass spectrometry by methods described previously [53]. In brief, citalopram and escitalopram were extracted from serum by liquidliquid extraction using a mixture of hexane/butanol/ acetonitrile $(93 / 5 / 2)$ as extraction solvent. Sertraline, fluoxetine and norfluoxetine were extracted from serum by liquid-liquid extraction using butyl chloride as extraction solvent. All analytes were then quantified on an Agilent MSD 1100 LC-MS system (Agilent Technologies, Palo Alto, CA, USA) after separation on $\mathrm{C} 18$ columns, and subsequent detection as pseudomolecular $(M+1)$ ions. Internal standards were used. Together with the unknown patient samples, each analytical series contained seven calibrators covering therapeutic, subtherapeutic, and toxic concentrations. In addition, six quality-control samples with representative target concentrations were included. The limits of quantification were $5 \mathrm{nmol} / \mathrm{L}$ for sertraline and 10 $\mathrm{nmol} / \mathrm{L}$ for citalopram, escitalopram, fluoxetine and norfluoxetine. Accuracy was controlled routinely with external control samples, and precision was calculated from the quality-control samples. In general, the inter-assay coefficients of variation were less than $10 \%$. The methods were linear in the concentration ranges concerned.

\section{Statistics}

Four genes, CRHR1, NPY, SRD5A2 and AKR1C4 were expressed in less than $50 \%$ of the samples, evenly distributed between groups, and were excluded from further analyses. Extreme outliers (> 4.9 SD) were removed from the dataset ( $n=16$ data points).
Demographic data were compared using Chi-square tests, one-way ANOVA, or Kruskal-Wallis test, with Tukey HSD or Dunn's test as post hoc test, respectively. Testing for normal distribution was done by the Shapiro-Wilk test. While the majority of $\Delta \mathrm{Ct}$ values were normally distributed, some were skewed; thus, data is presented as medians with interquartile ranges (IQRs). Statistical comparisons between groups were performed by one-way ANOVA or the Kruskal-Wallis test, depending on the distribution of the individual variable. When the results of ANOVA were significant, post hoc tests were pursued with the Tukey HSD test for normally distributed variables and the Dunn's test for skewed variables. In addition, correction for multiple testing was performed according to Bonferroni. Protein expression was compared between groups by the Kruskal-Wallis test, followed by Dunn's test, and protein expression data is presented as medians (IQR). Correlation between placental gene and protein expression was done by Spearman correlation. Statistical analyses were performed using IBM SPSS software (versions 24.0 and 25.0). Values of $p<0.05$ were considered statistically significant.

\section{Results \\ Clinical characteristics}

Demographic and clinical variables of the study groups are given in Table 1. The three study groups did not differ in terms of age and BMI, but women with untreated depression more often continued smoking during pregnancy, and women on antidepressant treatment more often had previous children in comparison with the healthy controls. In addition, women on antidepressant treatment had a shorter gestational length at delivery than those in the other two study groups.

Women with untreated depression had higher scores of self-rated depression (EPDS) at gestational weeks 17 and 32 in comparison with the controls (Table 1). A similar pattern was noted in women on antidepressant treatment, although their self-rated depression scores at the same time points were lower than among the untreated depressed women $(p=0.009$ and $p=0.002$, respectively).

The 45 women on antidepressant treatment were most often using sertraline $(n=17)$, followed by fluoxetine $(n=13)$, citalopram $(\mathrm{n}=13)$ and escitalopram $(n=2)$. According to the medical records, 39 (86.7\%) had been using antidepressant treatment throughout pregnancy, two women during the first half of pregnancy and four women during the second half of pregnancy. Blood samples at parturition were available in 41 cases. Of these, 28 showed detectable concentrations of antidepressant drugs (Table 2). 
Table 1 Demographic and clinical variables in the study group

\begin{tabular}{|c|c|c|c|c|c|c|c|}
\hline Variable & $\begin{array}{l}\text { Healthy controls } \\
\text { (n 47) }\end{array}$ & $\begin{array}{l}\text { Women with } \\
\text { untreated } \\
\text { depression } \\
(n \text { 25) }\end{array}$ & $\begin{array}{l}\text { Women on } \\
\text { antidepressant } \\
\text { treatment } \\
(n 45)\end{array}$ & $p^{*}$ & $\begin{array}{l}\text { p } \\
\text { untreated } \\
\text { depression vs. } \\
\text { controls }\end{array}$ & $\begin{array}{l}p \\
\text { antidepressant } \\
\text { treatment vs. } \\
\text { controls }\end{array}$ & $\begin{array}{l}\text { p } \\
\text { antidepressant } \\
\text { treatment vs. } \\
\text { untreated depression }\end{array}$ \\
\hline Age, years & $30.3 \pm 3.5$ & $30.3 \pm 4.9$ & $31.2 \pm 4.8$ & 0.560 & & & \\
\hline $\mathrm{BMI}, \mathrm{kg} / \mathrm{m}^{2}$ & $25.7 \pm 4.7$ & $25.0 \pm 4.4$ & $26.7 \pm 5.0$ & 0.339 & & & \\
\hline Nordic origin, n (\%) & $46(97.9)$ & $23(92.0)$ & $42(93.3)$ & 0.302 & & & \\
\hline University education, n (\%) & $34(82.9)$ & $16(64.0)$ & $28(70.0)$ & 0.489 & & & \\
\hline Parous, n (\%) & $19(40.4)$ & $14(56.0)$ & $30(66.7)$ & 0.040 & 0.207 & 0.012 & 0.378 \\
\hline Smoking during pregnancy, n (\%) & 0 & $3(12.0)$ & $1(2.2)$ & 0.024 & 0.039 & 0.489 & 0.127 \\
\hline Mode of delivery & & & & 0.460 & & & \\
\hline Vaginal, n (\%) & $40(85.1)$ & $21(84.0)$ & $34(75.6)$ & & & & \\
\hline Planned CS, n (\%) & $2(4.3)$ & $2(8.0)$ & $7(15.6)$ & & & & \\
\hline Emergency CS, n (\%) & $5(10.6)$ & $2(8.0)$ & $4(8.9)$ & & & & \\
\hline Gestational length, days & $282 \pm 7$ & $282 \pm 8$ & $276 \pm 9$ & 0.001 & 0.995 & 0.001 & 0.007 \\
\hline Birthweight, grams & $3697 \pm 587$ & $3769 \pm 427$ & $3640 \pm 437$ & 0.571 & & & \\
\hline EPDS in gestational week 17 & $2(1-5)$ & $13(11-16)$ & $7(5-11)$ & 0.001 & 0.001 & 0.001 & 0.009 \\
\hline EPDS in gestational week 32 & $3(1.5-5)$ & $15(13-16)$ & $7(5-12)$ & 0.001 & 0.001 & 0.001 & 0.002 \\
\hline
\end{tabular}

Data presented as mean \pm SD, median (IQR) or $n$ (\%). Statistics by Chi-square tests*, one-way ANOVA*, or Kruskal-Wallis test*. Post hoc tests by Tukey HSD or Dunn's test. Frequencies given in relation to available responses. BMI Body Mass Index, CS Caesarean Section, EPDS Edinburgh Postnatal Depression Scale, SD standard deviation, IQR interquartile range

\section{Placental gene expression}

Overall, following correction for multiple testing, none of the examined genes were differentially expressed between healthy controls, women with untreated depression and women on antidepressant treatment (Table 3).

Nominally significant findings, i.e. not corrected for multiple comparisons, were noted for HTR1A (5-hydroxytryptamine (5-HT)/serotonin receptor $1 \mathrm{~A}), N G F$ and NPY2R (neuropeptide Y2 receptor) (Table 3). These findings remained for HTR1A and NPY2R when analyses were restricted to women with detectable serum concentrations of antidepressant drugs at delivery (median $\triangle \mathrm{Ct}$ for HTR1A of 9.1 (IQR 7.9-11.8), $p=0.043$ and median $\triangle \mathrm{Ct}$ for NPY2R of 10.6 (IQR 8.4$12.4), p=0.019)$. Post hoc analyses revealed that women with untreated depression had higher gene expression of HTR1A, $(p=0.039)$ and NPY2R $(p=0.025)$ than healthy controls, whereas women on antidepressant treatment had similar expression levels of HTR1A and $N P Y 2 R$ as healthy controls (Fig. 1). No differences in serotonin (SLC6A4) or noradrenaline (SLC6A2) transporters or in any of the enzymes associated with serotonin synthesis or degradation (tryptophan hydroxylase 1 (TPH1), and 2 (TPH2), $A A D C$, catechol-Omethyltransferase $(C O M T)$ and $M A O A)$ ) were noted between the groups. Further, post hoc analyses revealed that placental gene expression of $N G F$ was higher in women with antidepressant treatment than in healthy controls ( $p=0.038$; Fig. 1$)$. The placental NGF gene expression was higher, but not statistically significant, when restricting the analysis to women with detectable levels of antidepressant drugs at delivery (median $\Delta \mathrm{Ct}$ for NGF of 8.3 (IQR 7.8-8.9), $p=0.056$ ).

Further analyses were conducted within the group of women on antidepressant treatment, comparing those with and without detectable serum concentrations. With the exception of $C Y P 3 A 4$, which showed greater expression in women with detectable serum concentrations of antidepressants ( $\Delta \mathrm{Ct} 10.5$ (IQR 7.6-11.7) vs. $\Delta \mathrm{Ct} 12.5$ (IQR 11.1-13.1), $p=0.010$ ), no differentially expressed

Table 2 Maternal serum concentrations of antidepressant drugs at parturition in 41 women from whom blood samples were available

\begin{tabular}{|c|c|c|c|c|}
\hline Antidepressant drug & Analyzed, n & Detectable concentration, n & $\begin{array}{l}\text { Mean } \pm \text { SD } \\
\mathrm{nmol} / \mathrm{l}\end{array}$ & $\begin{array}{l}\min -\max \\
\mathrm{nmol} / \mathrm{l}\end{array}$ \\
\hline Sertraline & 15 & 8 & $41.1 \pm 71.0$ & $8-216$ \\
\hline Fluoxetine $^{a}$ & 12 & 11 & $420 \pm 242$ & $36-739$ \\
\hline Citalopram & 12 & 9 & $102 \pm 55$ & $21-208$ \\
\hline Escitalopram & 2 & 0 & - & - \\
\hline
\end{tabular}

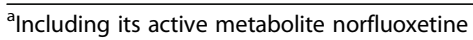


Table 3 Gene expression in placental tissue from healthy controls, women with untreated depression and women on antidepressant treatment

\begin{tabular}{|c|c|c|c|c|c|c|c|c|}
\hline \multirow[b]{2}{*}{ Gene } & \multicolumn{2}{|c|}{$\begin{array}{l}\text { Healthy controls } \\
(n \text { 47) }\end{array}$} & \multicolumn{2}{|c|}{$\begin{array}{l}\text { Women with untreated depression } \\
\text { (n 25) }\end{array}$} & \multicolumn{2}{|c|}{$\begin{array}{l}\text { Women on antidepressant treatment } \\
\text { ( } n \text { 45) }\end{array}$} & \multirow[b]{2}{*}{$p$} & \multirow[b]{2}{*}{$P$ bonferroni } \\
\hline & $n$ & Median (IQR) & $n$ & Median (IQR) & $n$ & Median (IQR) & & \\
\hline NPY2R & 40 & $12.3(10.1-13.3)$ & 20 & $9.7(9.1-11.7)$ & 37 & $10.9(9.3-12.6)$ & 0.024 & 0.960 \\
\hline NGF & 47 & $8.8(8.1-9.5)$ & 25 & $8.4(8.3-8.9)$ & 45 & $8.3(7.8-9.0)$ & 0.049 & 1.984 \\
\hline HTRIA & 34 & $10.8(9.6-12.3)$ & 21 & $9.0(7.7-11.3)$ & 27 & $10.4(8.8-11.7)$ & 0.049 & 1.988 \\
\hline OXTR & 47 & $9.5(8.4-11.1)$ & 25 & $9.3(7.4-10.0)$ & 45 & $8.9(7.9-10.3)$ & 0.081 & \\
\hline$B D N F$ & 47 & $6.3(5.9-6.8)$ & 25 & $6.0(5.2-6.4)$ & 45 & $6.4(5.8-6.7)$ & 0.091 & \\
\hline $\mathrm{CRH}$ & 47 & $0.7(-0.2-2.3)$ & 24 & $0.1(-1.0-1.1)$ & 45 & $1.0(-0.1-2.1)$ & 0.102 & \\
\hline $\mathrm{NR} 3 \mathrm{Cl}$ & 47 & $3.0(2.6-3.4)$ & 25 & $2.8(2.0-3.0)$ & 45 & $2.8(2.3-3.2)$ & 0.133 & \\
\hline$M A O A$ & 47 & $1.0(0.7-1.6)$ & 25 & $0.7(0.3-1.1)$ & 45 & $1.1(0.6-1.5)$ & 0.153 & \\
\hline TPH1 & 46 & $11.7(10.7-12.7)$ & 24 & $12.2(11.3-12.7)$ & 44 & $11.6(10.8-12.3)$ & 0.189 & \\
\hline$R A F-1$ & 47 & $5.1(4.7-5.4)$ & 25 & $4.8(4.5-5.2)$ & 45 & $5.0(4.7-5.3)$ & 0.193 & \\
\hline HTR3E & 47 & $9.9(8.9-10.8)$ & 24 & $9.1(8.7-10.4)$ & 45 & $9.9(8.7-10.8)$ & 0.195 & \\
\hline ROCK2 & 47 & $3.0(2.7-3.3)$ & 25 & $2.9(2.5-3.1)$ & 44 & $2.9(2.5-3.3)$ & 0.204 & \\
\hline$A A D C$ & 33 & $11.4(10.0-12.3)$ & 19 & $11.5(8.8-13.9)$ & 30 & $10.8(8.8-11.9)$ & 0.206 & \\
\hline OXT & 32 & $12.9(11.4-14.0)$ & 18 & $12.4(11.1-12.7)$ & 25 & $12.6(11.5-13.2)$ & 0.280 & \\
\hline SRD5A1 & 47 & $9.2(8.8-9.6)$ & 25 & $9.0(8.6-9.4)$ & 45 & $9.2(8.7-9.6)$ & 0.301 & \\
\hline ROCK1 & 46 & $4.1(3.8-4.4)$ & 25 & $3.8(3.7-4.2)$ & 45 & $3.8(3.5-4.1)$ & 0.313 & \\
\hline COMT & 45 & $2.9(2.2-3.2)$ & 25 & $3.1(2.8-3.3)$ & 43 & $2.9(2.5-3.4)$ & 0.318 & \\
\hline TPH2 & 46 & $10.4(9.3-12.2)$ & 25 & $11.1(10.4-11.7)$ & 44 & $11.3(10.2-12.1)$ & 0.356 & \\
\hline HSD11B1 & 47 & $5.6(4.8-6.4)$ & 25 & $5.8(4.2-6.3)$ & 45 & $5.9(5.2-6.4)$ & 0.426 & \\
\hline CYPЗА4 & 26 & $12.0(9.5-13.5)$ & 14 & $11.3(9.9-12.7)$ & 19 & $11.1(8.6-12.5)$ & 0.456 & \\
\hline CYP2D6 & 47 & 8.7 (7.9-9.7) & 25 & $8.7(7.6-9.1)$ & 45 & $8.8(8.0-9.4)$ & 0.478 & \\
\hline GABRG2 & 43 & $9.9(8.9-10.7)$ & 23 & $10.3(9.0-11.8)$ & 42 & $9.7(8.7-11.3)$ & 0.478 & \\
\hline CYPIA2 & 25 & $11.7(10.7-14.1)$ & 19 & $10.9(9.8-12.1)$ & 29 & $11.4(9.6-13.1)$ & 0.506 & \\
\hline PTGDS & 47 & $2.0(1.5-2.7)$ & 25 & $1.9(1.1-2.6)$ & 45 & $1.9(1.0-2.6)$ & 0.539 & \\
\hline HSD11B2 & 47 & $2.5(1.7-3.3)$ & 24 & $1.9(1.6-2.6)$ & 45 & $2.0(1.4-3.1)$ & 0.573 & \\
\hline SLC6A2 & 47 & $3.6(3.1-4.4)$ & 25 & $3.5(3.1-4.2)$ & 45 & $3.7(3.5-4.3)$ & 0.624 & \\
\hline SLC6A4 & 46 & $3.7(3.3-4.1)$ & 24 & $3.8(3.5-4.1)$ & 45 & $3.8(3.4-4.4)$ & 0.669 & \\
\hline $\mathrm{CDH} 2$ & 47 & $10.1(8.3-11.8)$ & 25 & $10.0(8.8-11.8)$ & 44 & $9.4(8.5-11.0)$ & 0.685 & \\
\hline NTRK1 & 37 & $10.1(7.5-11.8)$ & 18 & $9.0(7.3-11.4)$ & 31 & $9.5(8.0-10.7)$ & 0.724 & \\
\hline$A L A D$ & 47 & $4.6(4.4-4.9)$ & 25 & $4.6(4.3-4.9)$ & 45 & $4.6(4.3-5.0)$ & 0.726 & \\
\hline NPY1R & 47 & $9.6(9.0-10.0)$ & 25 & $9.6(8.7-10.0)$ & 45 & $9.6(8.5-10.5)$ & 0.769 & \\
\hline CREB1 & 47 & $4.2(3.7-4.4)$ & 25 & $3.9(3.7-4.4)$ & 45 & $4.0(3.7-4.4)$ & 0.824 & \\
\hline$C R H B P$ & 47 & $6.5(5.4-7.6)$ & 25 & $6.4(5.3-8.0)$ & 45 & $6.7(5.5-8.1)$ & 0.851 & \\
\hline$A B C B 1$ & 47 & $5.3(4.1-5.8)$ & 25 & $4.8(4.1-5.9)$ & 45 & $5.1(4.1-6.7)$ & 0.855 & \\
\hline VEGFA & 47 & $4.6(3.6-5.4)$ & 25 & $4.5(3.6-5.4)$ & 45 & $4.4(3.6-5.0)$ & 0.860 & \\
\hline HTR7 & 46 & $10.1(9.1-11.6)$ & 25 & $10.2(9.2-10.9)$ & 45 & $10.1(8.9-10.8)$ & 0.879 & \\
\hline PGF & 47 & $0.1(-1.0-0.7)$ & 25 & $-0.1(-1.0-0.9)$ & 45 & $-0.1(-0.6-0.3)$ & 0.893 & \\
\hline CCK & 46 & $10.4(8.4-11.3)$ & 24 & $10.2(8.2-11.3)$ & 45 & $9.4(8.1-11.4)$ & 0.923 & \\
\hline NTRK2 & 47 & $9.2(8.2-9.9)$ & 24 & $9.1(8.6-9.9)$ & 44 & $9.0(8.4-9.8)$ & 0.956 & \\
\hline VIP & 46 & $10.1(9.2-10.9)$ & 25 & $9.8(9.4-10.5)$ & 45 & $9.9(9.4-10.6)$ & 0.971 & \\
\hline
\end{tabular}


placental genes were detected between these two groups (data not shown).

\section{Placental protein expression}

Genes nominally significantly different between groups were selected for placental protein expression determination. NGF was not included in the protein analyses, as this has previously been reported by our group [29]. Immunohistochemical staining of HTR1A showed medium-strong intensity in placental trophoblasts and endothelial cells, and medium intensity in stromal cells, whereas staining of NPY2R displayed medium intensity in trophoblasts and weak intensity in endothelial and stromal cells (Fig. 2). HTR1A staining intensity in trophoblasts differed between groups (Table 4), and the difference remained significant in analyses restricted to the treated women with detectable antidepressant serum levels, compared with healthy controls and untreated depressed women $(p=0.043)$. The highest level of HTR1A expression was noted in women on antidepressant treatment, in comparison with healthy controls $(p=0.031$; Fig. 3). No difference in endothelial and stromal-cell expression of HTR1A was noted between groups. No correlation between placental gene and protein expression of HTR1A was noted (trophoblasts, rho $=0.004$, $p=0.98$; endothelial cells, rho $=-0.18, p=0.27$; stromal cells, rho $=-0.06, p=0.71$ ).

No difference between groups in placental NPY2R protein expression was confirmed. Gene expression of NPY2R was negatively correlated with corresponding protein expression in placental endothelial and stromal cells (trophoblasts, rho $=-0.11, p=0.43$; endothelial cells, rho $=-0.35, p=0.009$; stromal cells, rho $=-0.30$, $p=0.025)$.

\section{Discussion}

Following correction for multiple testing, our study did not reveal any significant differences in placental gene expression, of the 44 tested genes, between women with antenatal depression, women with antidepressant treatment, and healthy controls. However, given the pregnancy outcomes at stake, i.e. placental function and consequent fetal well-being, it can be argued that a statistically correct approach may conceal clinically relevant findings. For this reason, we have also reported on the few nominally significant transcripts that were detected primarily in women with antenatal depression. All in all, the enhanced gene expression of HTR1A in placentas from women with untreated depression, together with the stronger immunohistochemical staining of HTR1A in the treatment group, could strengthen the theory of the involvement of HTR1A in maternal depression and placental function. HTR $1 A$ has previously been identified in placental tissue [54]. Serotonin receptors in the placenta are important for maintenance of the normal development of the fetal brain $[55,56]$. Alterations in the placental expression of serotonin receptors have been associated with maternal stress [56] and infant neurodevelopment [57]. While HTR1A has previously been described in the trophoblasts of human placenta, at present no information on the role of this receptor in placental function has been published. Notably, the observed differences in placental HTR1A gene and protein expression were not accompanied by changes in the serotonin or noradrenaline transporters or in any of the enzymes associated with serotonin synthesis or degradation in our study cohort, at least at gene-expression level.

$5-\mathrm{HT}_{1 \mathrm{~A}}$ receptors can be found as both heteroreceptors and autoreceptors [58-60]. Upon binding of the neurotransmitter to the autoreceptor, a negative feedback loop inhibits further release of the neurotransmitter [61]. Prolonged administration of SSRIs will decrease the autoreceptors' sensitivity for neurotransmitters, leading to an elevated concentration of synaptic serotonin [61, $62]$. While presynaptic $5-\mathrm{HT}_{1 \mathrm{~A}}$ autoreceptors may delay the effect of antidepressant treatment, the stimulation of postsynaptic $5-\mathrm{HT}_{1 \mathrm{~A}}$ receptors in corticolimbic networks
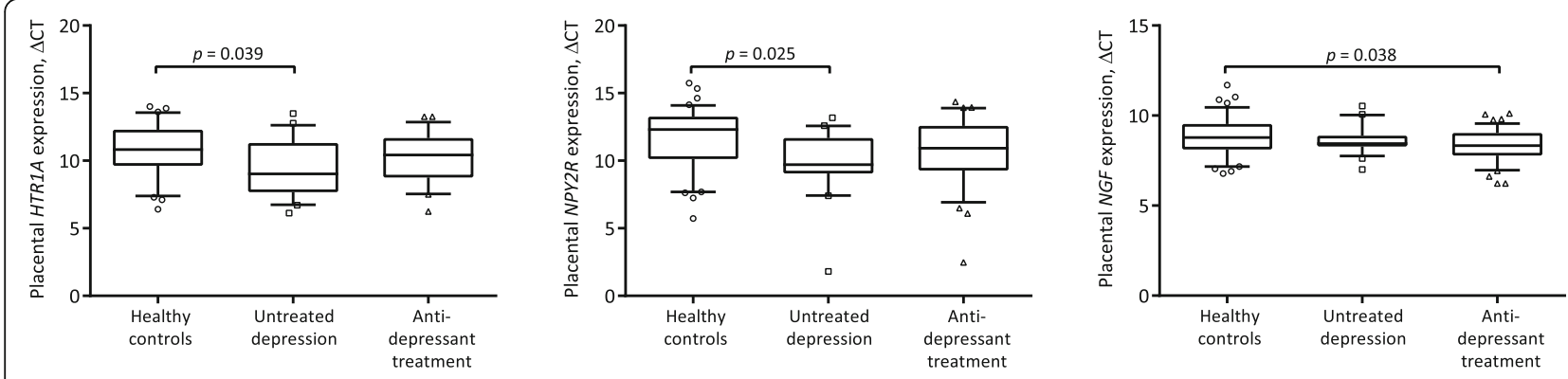

Fig. 1 Placental gene expression (median $\Delta C \mathrm{Ct}, \mathrm{IQR})$ in women with antenatal depression $(n=25)$, antidepressant treatment $(n=45)$, and healthy controls $(n=47)$. Women with untreated depression had higher gene expression of HTR1A, $p=0.039$ (Tukey HSD), and NPY2R, $p=0.025$ (Dunn's test), than healthy controls. The gene expression of NGF was higher in women with antidepressant treatment than in healthy controls, $p=0.038$ (Tukey HSD) 

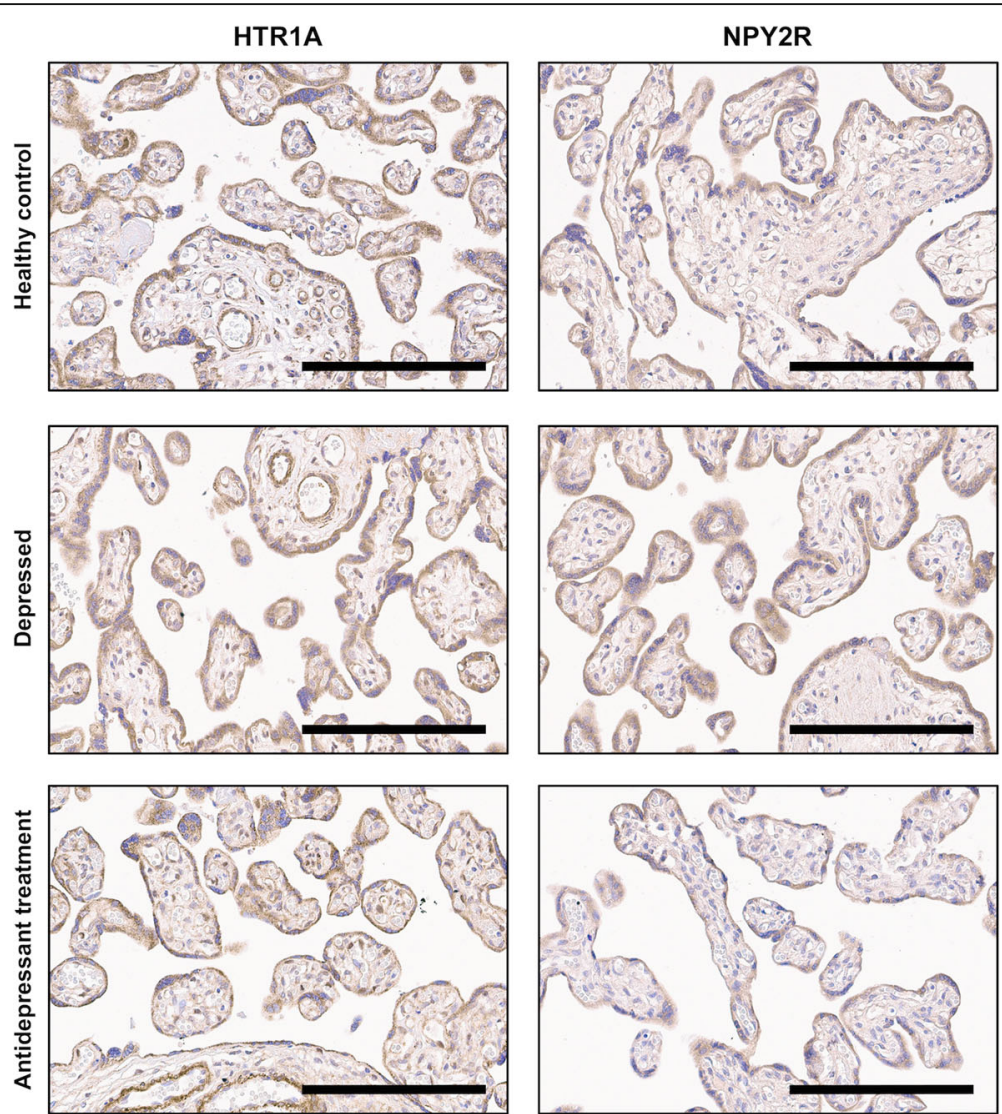

Fig. $2 \mathrm{Imm}$ unohistochemically stained placental tissue from representative women with antenatal depression, antidepressant treatment, and healthy controls. Antibodies: anti-HTR1A (PA5-28090, rabbit, Thermo Fisher Scientific, dilution 1:500), anti-NPY2R (PA1-41576, rabbit, Thermo Fisher Scientific, dilution 1:250). Scale bar $=200 \mu \mathrm{m}$. Objective 20x

is beneficial for antidepressant action [63]. Moreover, polymorphisms in the gene encoding $5-\mathrm{HT}_{1 \mathrm{~A}}[64,65]$, and altered regulation of $5-\mathrm{HT}_{1 \mathrm{~A}}[66]$ have been associated with depression. A study by Olivier et al. has revealed increased $5-\mathrm{HT}_{1 \mathrm{~A}}$ receptor sensitivity in prenatally fluoxetine-exposed rats, which may, in part, explain the neurodevelopmental changes observed in these animals [67].
In this study, NGF gene expression was higher in placental tissue from women using antidepressants during pregnancy. This finding is in line with previous data, where we showed that NGF protein expression was increased in both trophoblasts and endothelial cells from women using antidepressants during pregnancy compared with NGF protein expression in placentas from depressed and healthy controls [29]. Together, these

Table 4 Placental protein expression of HTR1A and NPY2R in healthy controls, women with untreated depression and women on antidepressant treatment

\begin{tabular}{llll}
\hline & $\begin{array}{l}\text { Healthy controls } \\
(n \text { 37) }\end{array}$ & $\begin{array}{l}\text { Women with untreated depression } \\
(n \text { 13) }\end{array}$ & $\begin{array}{l}\text { Women on antidepressant treatment } \\
(n \text { 21) }\end{array}$ \\
\hline HTR1A & & & \\
Trophoblasts & $238(206-263)$ & $225(213-244)$ & $263(238-288)$ \\
$\quad$ Endothelial cells & $225(175-238)$ & $225(169-263)$ & $225(206-263)$ \\
Stroma cells & $175(138-213)$ & $175(156-194)$ & $175(175-231)$ \\
NPY2R & & & $200(163-238)$ \\
Trophoblasts & $188(156-213)$ & $213(163-225)$ & $50(50-81)$ \\
Endothelial cells & $63(50-63)$ & $63(50-113)$ & $50(50-81)$ \\
Stroma cells & $50(50-63)$ & $63(50-113)$ & 0.284 \\
\hline
\end{tabular}

Data presented as median $\mathrm{H}$-score (IQR). Statistics by Kruskal-Wallis test 

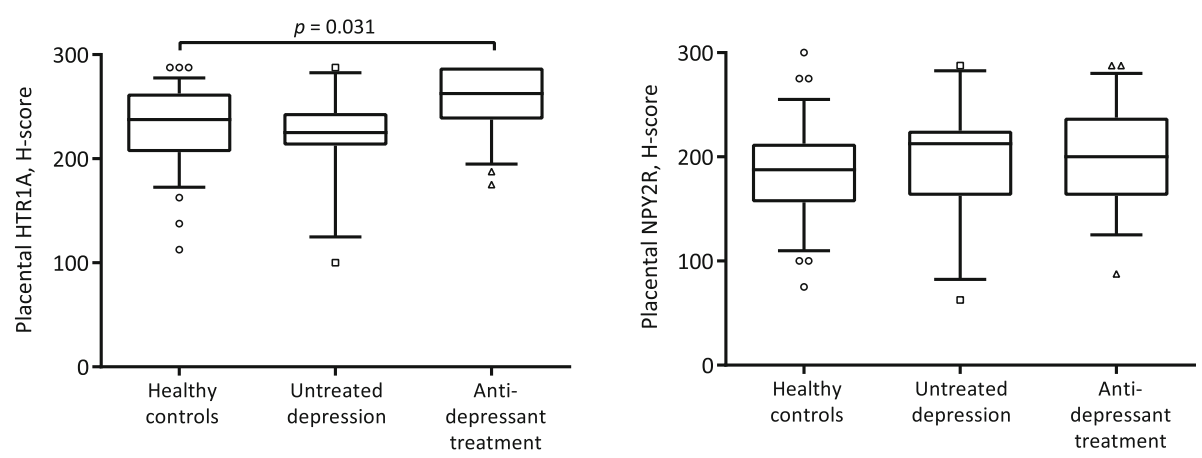

Fig. 3 Protein expression (median H-score, IQR) in placental trophoblasts in women with antenatal depression $(n=13)$, antidepressant treatment $(n=21)$, and healthy controls $(n=37)$. The highest HTR1A expression was noted in women on antidepressant treatment, in comparison with healthy controls, $p=0.031$ (Dunn's test). No difference between groups in placental NPY2R protein expression was confirmed

results indicate that SSRI use during pregnancy may affect NGF signalling in the placenta.

The neuropeptide Y2 receptor (NPY2R), which exhibited enhanced gene expression in untreated depressed women, is known to have appetite-inhibiting properties $[68,69]$. In addition to food intake, members of the NPY family exert effects on psychomotor activity, regulation of endocrine secretion, energy homeostasis, and effects on the cardiovascular system [68]. There are also studies showing increased levels of NPY in pre-eclamptic women, suggesting involvement in placental function [70]. NPY has been identified in the brain and placenta in rats [71]. Members of the NPY family have also been implicated in CNS functions in primates, where, for example, activation of NPY2R is thought to exert anxiogenic actions [72]. Our results, however, revealed unchanged protein expression in the placenta in relation to the exposures involved. Thus, this finding needs replication before any meaningful interpretations can be made.

The major strengths of this study include the sample of placentas from obstetrically healthy women with stringent definition of antenatal depression, and women on antidepressant treatment. Further, the use of SSRIs is validated by serum concentrations of the actual drug in question. Additional strengths are age- and BMImatched controls, and validation of the gene-expression results at a protein level by immunohistochemistry. Even so, some limitations need to be mentioned. The use of human placentas inevitably introduces great variability, in this study seen in the various types, doses and duration of antidepressant treatment. Similarly, the severity and duration of antenatal depression also differed between women. This heterogeneity may influence and potentially dilute important findings, but on the other hand, restriction to more stringent samples would affect power in individual analyses. Another limitation is the lower number of samples available for protein analysis compared with those available for gene expression analysis (71 out of 117). Only 28 of 41 women had detectable serum concentrations of an antidepressant drug at delivery. While the serum concentrations validate the medical reports of ongoing SSRI use, it should be stressed that non-confirmation of SSRI treatment in serum does not necessarily mean the placenta has not been exposed to treatment during pregnancy. Many women are aware of neonatal complications from SSRI use during late pregnancy [73], and some discontinue in preparation for delivery to avoid such problems [74, 75]. Clearly, no difference in results was noted when analyses were restricted to women with confirmed SSRI use, and there were also no differences in placental gene expression between women with detectable and non-detectable antidepressant serum concentrations.

Investigators have described associations between poor mental health, impaired placental function, and poor pregnancy outcomes such as preterm birth and low birth weight [13-15], but the underlying biological mechanisms are not fully understood. More research is required to elucidate the causal relationships between these factors. Our findings may be interpreted as being both reassuring and worrying for women who suffer from antenatal depression and need treatment for their condition. The genes investigated were primarily chosen because they have been linked to depression in various human and animal studies. Thus, at the gene level, it may not be surprising that the findings of interest were noted only among women with antenatal depression, whereas SSRI users had similar gene-expression levels as the healthy controls. While this finding may appear reassuring, potentially suggesting that treatment of antenatal depression normalizes placental gene expression, it is contradicted by the findings at the protein level. If we had chosen genes on the basis of their association with antidepressant use, we might have revealed a different picture. Further reassuring findings were that some of 
the genes we studied are known to have an impact on long-term fetal health, such as HSD11B1 and 2, which control the shuttling of cortisol to the fetus. While maternal stress is known to affect this placental enzyme [35-37, 39], we found no evidence that antenatal depression or antidepressant treatment had such effects. Notably, however, gene expression does not equal function, and previous studies from our group have demonstrated that the maternal cortisone:cortisol ratio, as a functional measure of this enzyme, is positively associated with birth weight in women with psychiatric disease [76]. Of concern, this study has demonstrated differential expression of serotonin receptor $1 \mathrm{~A}$ and NPY2 receptor, both of which currently are of unclear relevance as regards placental function. Previous microarray studies have demonstrated a multitude of genes that are differentially expressed, especially in women on antidepressant treatment [30], and absence of findings in our study should not be interpreted as the full picture, or that SSRI use during pregnancy is without harm. Clearly, further studies in this area are needed, and the review by Gentile and Fusco describes the importance in more rigorous assessments including ultrasound studies on fetal responses to maternal mood and antidepressant medication and also analyses of epigenetic modifications associated with antenatal depression and antidepressant treatment [28].

\section{Conclusion}

The differential expression of HTR1A at both the gene and protein level that was revealed in this study suggests the involvement of HTR1A in the effect of antenatal depression on biological mechanisms in the placenta. More research is needed to elucidate the roles of depression and antidepressant treatment on placental gene and protein expression, especially as regards HTR1A, and, further, the effect on the fetus.

\section{Supplementary information}

Supplementary information accompanies this paper at https://doi.org/10 1186/s12884-019-2586-y.

Additional file 1: Table $\mathbf{S 1 .}$ Gene symbols, gene names, TaqMan probes.

\footnotetext{
Abbreviations

AADC: aromatic I-amino acid decarboxylase; AKR1C4: 3a-hydroxysteroid dehydrogenase; BASIC: Biology, Affect, Stress, Imaging, Cognition; BDNF: brain-derived neurotrophic factor; BMI: body mass index; BSA: bovine serum albumin; COMT: catechol-O-methyltransferase; $\mathrm{CRH}$ : corticotrophinreleasing hormone; DAB: 3,3'-diaminobenzidine; EPDS: Edinburgh Postnatal Depression Scale; HPA: hypothalamic-pituitary-adrenal; HRP: horseradish peroxidase; HSD11B: 11 hydroxysteroid dehydrogenase; HTR1A: 5hydroxytryptamine $(5-\mathrm{HT})$ /serotonin receptor $1 \mathrm{~A}$; IQR: interquartile range; MAOA: monoamine oxidase A; MINI: Mini International Neuropsychiatric Interview; NGF: nerve growth factor; NPY2R: neuropeptide Y2 receptor; OXTR: oxytocin receptor; PBS: phosphate-buffered saline; RT: room
}

temperature; SLC6A2: sodium-dependent noradrenaline transporter; SLC6A4: sodium-dependent serotonin transporter; SRD5A: 5a-reductase; SSRI: selective serotonin reuptake inhibitor; TLDA: TaqMan low-density array; $\mathrm{TPH}$ : tryptophan hydroxylase; VEGF: vascular endothelial growth factor

\section{Acknowledgements}

The authors want to thank all women who participated in this study.

\section{Authors' contributions}

ISP, JO, HA and AS were involved in the conception and design of the study. ÅE prepared all samples and carried out the immunohistochemistry. ÅE and TKK scored the immunohistochemistry slides. RF and ESV performed the qPCRs. OS performed the SSRI concentration measurements. ÅE, ISP and JO analysed the overall data. ÅE, ISP, JO, CH and SL made substantial contributions to interpretation of the results. $\AA$ E and ISP drafted the article. All authors revised the manuscript critically in connection with important intellectual content and approved the final version.

\section{Funding}

This study was supported by grants from the Swedish research council (VR:521-2013-2339), and from Födelsefonden and Lions. The funding bodies have not had any role in the design of the study and collection, analysis, and interpretation of data, and in writing the manuscript. No support was obtained from any pharmaceutical company.

\section{Availability of data and materials}

The data generated in this study can be found in the Figshare repository https://figshare.com/s/c0d6bdb9dd00d777ff8e.

Ethics approval and consent to participate

The study was approved by the Regional Ethical Review Board, Uppsala, Sweden, and performed in accordance with relevant guidelines and regulations (Dnr 2009/171, approval July 1, 2009). Written informed consent is obtained from women who choose to participate in the BASIC project.

Consent for publication

Not applicable.

\section{Competing interests}

ISP serves occasionally on advisory boards and act as an invited speaker at scientific meetings for MSD, Bayer Health Care, Lundbeck A/S, and Gedeon Richter. None of the other authors have any competing interests.

\section{Author details}

${ }^{1}$ Department of Women's and Children's Health, Uppsala University, 75185 Uppsala, Sweden. 'Department of Immunology, Genetics and Pathology, Uppsala University, 75185 Uppsala, Sweden. ${ }^{3}$ Department of Physiology and Pharmacology, Karolinska Institute, 17177 Stockholm, Sweden. ${ }^{4}$ Department of Clinical Pharmacology, St. Olav University Hospital, 7006 Trondheim, Norway. ${ }^{5}$ Department of Clinical and Molecular Medicine, Norwegian University of Science and Technology, 7491 Trondheim, Norway.

${ }^{6}$ Neurobiology, Unit Behavioral Neuroscience, Groningen Institute for Evolutionary Life Sciences, University of Groningen, 9747, AG, Groningen, The Netherlands.

Received: 14 February 2019 Accepted: 7 November 2019

Published online: 05 December 2019

\section{References}

1. Woody CA, Ferrari AJ, Siskind DJ, Whiteford HA, Harris MG. A systematic review and meta-regression of the prevalence and incidence of perinatal depression. J Affect Disord. 2017;219:86-92.

2. Gavin NI, Gaynes BN, Lohr KN, Meltzer-Brody S, Gartlehner G, Swinson T, Perinatal depression: a systematic review of prevalence and incidence. Obstet Gynecol. 2005;106(5 Pt 1):1071-83.

3. Andersson L, Sundstrom-Poromaa I, Bixo M, Wulff M, Bondestam K. aStrom $M$. point prevalence of psychiatric disorders during the second trimester of pregnancy: a population-based study. Am J Obstet Gynecol 2003;189(1):148-54

4. Gorman LL, O'Hara MW, Fiqueiredo B, Hayes S, Jacquemain F, Kammerer $\mathrm{MH}$, et al. Adaptation of the structured clinical interview for DSM-IV 
disorders for assessing depression in women during pregnancy and postpartum across countries and cultures. Br J Psychiatry Suppl. 2004;46:517-23.

5. Melville JL, Gavin A, Guo Y, Fan MY, Katon WJ. Depressive disorders during pregnancy: prevalence and risk factors in a large urban sample. Obstet Gynecol. 2010;116(5):1064-70.

6. Patkar AA, Bilal L, Masand PS. Pharmacotherapy of depression in pregnancy. Ann Clin Psychiatry. 2004;16(2):87-100.

7. The National Board of Health and Welfare. Sweden 2016. (www.socialstyrelsen.se),

8. Huybrechts KF, Palmsten K, Mogun H, Kowal M, Avorn J, Setoguchi-Iwata S, et al. National trends in antidepressant medication treatment among publicly insured pregnant women. Gen Hosp Psychiatry. 2013;35(3):265-71.

9. Kieler $\mathrm{H}$. The Nordic health registers - an important source when evaluating the safety of antidepressants during pregnancy. Clin Epidemiol. 2010;2:205-7.

10. El Marroun H, Jaddoe WW, Hudziak JJ, Roza SJ, Steegers EA, Hofman A, et al. Maternal use of selective serotonin reuptake inhibitors, fetal growth, and risk of adverse birth outcomes. Arch Gen Psychiatry. 2012;69(7):706-14.

11. Petersen I, Peltola T, Kaski S, Walters KR, Hardoon S. Depression, depressive symptoms and treatments in women who have recently given birth: UK cohort study. BMJ Open. 2018;8(10):e022152.

12. Charlton RA, Jordan S, Pierini A, Garne E, Neville AJ, Hansen AV, et al. Selective serotonin reuptake inhibitor prescribing before, during and after pregnancy: a population-based study in six European regions. BJOG. 2015; 122(7):1010-20.

13. Furu K, Kieler H, Haglund B, Engeland A, Selmer R, Stephansson O, et al. Selective serotonin reuptake inhibitors and venlafaxine in early pregnancy and risk of birth defects: population based cohort study and sibling design. BMJ. 2015;350:h1798.

14. Olivier JD, Akerud H, Kaihola H, Pawluski JL, Skalkidou A, Hogberg U, et al. The effects of maternal depression and maternal selective serotonin reuptake inhibitor exposure on offspring. Front Cell Neurosci. 2013;7:73.

15. Prady SL, Hanlon I, Fraser LK, Mikocka-Walus A. A systematic review of maternal antidepressant use in pregnancy and short- and long-term offspring's outcomes. Arch Womens Ment Health. 2018;21(2):127-40.

16. Wang YZ, S. Chapter 3, structure of the placenta. In: Vascular biology of the placenta. Morgan \& Claypool Life Sciences: San Rafael (CA); 2010.

17. Audette MC, Kingdom JC. Screening for fetal growth restriction and placental insufficiency. Semin Fetal Neonatal Med. 2018;23(2):119-25.

18. Hodyl NA, Aboustate N, Bianco-Miotto T, Roberts CT, Clifton VL, Stark MJ. Child neurodevelopmental outcomes following preterm and term birth: what can the placenta tell us? Placenta. 2017;57:79-86.

19. Sultana Z, Maiti K, Dedman L, Smith R. Is there a role for placental senescence in the genesis of obstetric complications and fetal growth restriction? Am J Obstet Gynecol. 2018;218(2S):S762-S73.

20. Reijnders IF, Mulders A, Koster MPH. Placental development and function in women with a history of placenta-related complications: a systematic review. Acta Obstet Gynecol Scand. 2018;97(3):248-57.

21. Hendrick V, Stowe ZN, Altshuler LL, Hwang S, Lee E, Haynes D. Placental passage of antidepressant medications. Am J Psychiatry. 2003;160(5):993-6.

22. Loughhead AM, Fisher AD, Newport DJ, Ritchie JC, Owens MJ, DeVane CL et al. Antidepressants in amniotic fluid: another route of fetal exposure. Am J Psychiatry. 2006;163(1):145-7.

23. Cikos S, Fabian D, Makarevich AV, Chrenek P, Koppel J. Biogenic monoamines in preimplantation development. Hum Reprod. 2011;26(9):2296-305.

24. Oufkir T, Arseneault M, Sanderson JT, Vaillancourt C. The 5-HT 2A serotonin receptor enhances cell viability, affects cell cycle progression and activates MEK-ERK1/2 and JAK2-STAT3 signalling pathways in human choriocarcinoma cell lines. Placenta. 2010:31(5):439-47.

25. Charnock-Jones DS, Burton GJ. Placental vascular morphogenesis. Baillieres Best Pract Res Clin Obstet Gynaecol. 2000;14(6):953-68.

26. Bhuiyan M, Petropoulos S, Gibb W, Matthews SG. Sertraline alters multidrug resistance phosphoglycoprotein activity in the mouse placenta and fetal blood-brain barrier. Reprod Sci. 2012;19(4):407-15.

27. Bonnin A, Goeden N, Chen K, Wilson ML, King J, Shih JC, et al. A transient placental source of serotonin for the fetal forebrain. Nature. 2011;472(7343):347-50.

28. Gentile S. Fusco ML. Placental and fetal effects of antenatal exposure to antidepressants or untreated maternal depression. J Matern Fetal Neonatal Med. 2017:30(10):1189-99.

29. Kaihola H, Olivier J, Poromaa IS, Akerud $\mathrm{H}$. The effect of antenatal depression and selective serotonin reuptake inhibitor treatment on nerve growth factor signaling in human placenta. PLoS One. 2015;10(1):e0116459.
30. Olivier JD, Akerud H, Skalkidou A, Kaihola H, Sundstrom-Poromaa I. The effects of antenatal depression and antidepressant treatment on placental gene expression. Front Cell Neurosci. 2014;8:465.

31. Kumsta R, Hummel E, Chen FS, Heinrichs M. Epigenetic regulation of the oxytocin receptor gene: implications for behavioral neuroscience. Front Neurosci. 2013;7:83.

32. Simons RL, Lei MK, Beach SRH, Cutrona CE, Philibert RA. Methylation of the oxytocin receptor gene mediates the effect of adversity on negative schemas and depression. Dev Psychopathol. 2017;29(3):725-36.

33. Galbally M, Ryan J. Van IM, Watson SJ, Spigset O, Lappas M, et al. maternal depression, antidepressant use and placental oxytocin receptor DNA methylation: findings from the MPEWS study.

Psychoneuroendocrinology. 2018;90:1-8.

34. Janssen AB, Capron LE, O'Donnell K, Tunster SJ, Ramchandani PG, Heazell $A E$, et al. Maternal prenatal depression is associated with decreased placental expression of the imprinted gene PEG3. Psychol Med. 2016:46(14):2999-3011.

35. Capron LE, Ramchandani PG, Glover V. Maternal prenatal stress and placental gene expression of NR3C1 and HSD11B2: the effects of maternal ethnicity. Psychoneuroendocrinology. 2018;87:166-72.

36. Togher KL, Treacy E, O'Keeffe GW, Kenny LC. Maternal distress in late pregnancy alters obstetric outcomes and the expression of genes important for placental glucocorticoid signalling. Psychiatry Res. 2017; 255:17-26.

37. Seth S, Lewis AJ, Saffery R, Lappas M, Galbally M. Maternal prenatal mental health and placental 11 beta-HSD2 gene expression: initial findings from the mercy pregnancy and emotional wellbeing study. Int J Mol Sci. 2015;16(11): 27482-96.

38. Reynolds RM, Pesonen AK, O'Reilly JR, Tuovinen S, Lahti M, Kajantie E, et al. Maternal depressive symptoms throughout pregnancy are associated with increased placental glucocorticoid sensitivity. Psychol Med. 2015;45(10): 2023-30.

39. O'Donnell KJ, Bugge Jensen A, Freeman L, Khalife N, O'Connor TG, Glover V. Maternal prenatal anxiety and downregulation of placental 11 beta-HSD2. Psychoneuroendocrinology. 2012;37(6):818-26.

40. Zhang W, Finik J, Dana K, Glover V, Ham J, Nomura Y. Prenatal depression and infant temperament: the moderating role of placental gene expression. Infancy. 2018:23(2):211-31.

41. Lahti-Pulkkinen M, Cudmore MJ, Haeussner E, Schmitz C, Pesonen AK, Hamalainen $\mathrm{E}$, et al. Placental morphology is associated with maternal depressive symptoms during pregnancy and toddler psychiatric problems. Sci Rep. 2018;8(1):791.

42. Cox JL, Holden JM, Sagovsky R. Detection of postnatal depression. Development of the 10-item Edinburgh postnatal depression scale. Br J Psychiatry. 1987;150:782-6.

43. Rubertsson C, Borjesson K, Berglund A, Josefsson A, Sydsjo G. The Swedish validation of Edinburgh postnatal depression scale (EPDS) during pregnancy. Nord J Psychiatry. 2011;65(6):414-8.

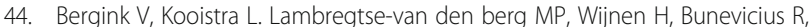
van Baar a, et al. validation of the Edinburgh depression scale during pregnancy. J Psychosom Res. 2011;70(4):385-9.

45. Ponder KL, Salisbury A, McGonnigal B, Laliberte A, Lester B, Padbury JF. Maternal depression and anxiety are associated with altered gene expression in the human placenta without modification by antidepressant use: implications for fetal programming. Dev Psychobiol. 2011:53(7):711-23.

46. Hannerfors AK, Hellgren C, Schijven D, lliadis SI, Comasco E, Skalkidou A, et al. Treatment with serotonin reuptake inhibitors during pregnancy is associated with elevated corticotropin-releasing hormone levels. Psychoneuroendocrinology. 2015;58:104-13.

47. Cottrell EC, Seckl JR, Holmes MC, Wyrwoll CS. Foetal and placental 11 betaHSD2: a hub for developmental programming. Acta Physiol (Oxf). 2014; 210(2):288-95.

48. Hellgren C, Akerud H, Skalkidou A, Backstrom T, Sundstrom-Poromaa I. Low serum allopregnanolone is associated with symptoms of depression in late pregnancy. Neuropsychobiology. 2014;69(3):147-53.

49. Hellgren C, Comasco E, Skalkidou A, Sundstrom-Poromaa I. Allopregnanolone levels and depressive symptoms during pregnancy in relation to single nucleotide polymorphisms in the allopregnanolone synthesis pathway. Horm Behav. 2017;94:106-13.

50. Andersen $\mathrm{CL}$, Jensen $\mathrm{J}$, Orntoft TF. Normalization of real-time quantitative reverse transcription-PCR data: a model-based variance estimation approach 
to identify genes suited for normalization, applied to bladder and colon cancer data sets. Cancer Res. 2004;64(15):5245-50.

51. Hirsch FR, Varella-Garcia M, Bunn PA Jr, Di Maria MV, Veve R, Bremmes RM, et al. Epidermal growth factor receptor in non-small-cell lung carcinomas: correlation between gene copy number and protein expression and impact on prognosis. J Clin Oncol. 2003;21(20):3798-807.

52. John T, Liu G, Tsao MS. Overview of molecular testing in non-small-cell lung cancer: mutational analysis, gene copy number, protein expression and other biomarkers of EGFR for the prediction of response to tyrosine kinase inhibitors. Oncogene. 2009;28(Suppl 1):S14-23.

53. Reis M, Aamo T, Spigset O, Ahlner J. Serum concentrations of antidepressant drugs in a naturalistic setting: compilation based on a large therapeutic drug monitoring database. Ther Drug Monit. 2009;31(1):42-56.

54. Huang $W Q$, Zhang $C L$, Di XY, Zhang RQ. Studies on the localization of 5hydroxytryptamine and its receptors in human placenta. Placenta. 1998; 19(8):655-61.

55. Velasquez JC, Goeden N, Bonnin A. Placental serotonin: implications for the developmental effects of SSRIs and maternal depression. Front Cell Neurosci. 2013;7:47.

56. St-Pierre J, Laurent L, King S, Vaillancourt C. Effects of prenatal maternal stress on serotonin and fetal development. Placenta. 2016:48(Suppl 1):S66-71.

57. Paquette AG, Lesseur C, Armstrong DA, Koestler DC, Appleton AA, Lester $B M$, et al. Placental HTR2A methylation is associated with infant neurobehavioral outcomes. Epigenetics. 2013;8(8):796-801.

58. Beck SG, Choi KC, List TJ. Comparison of 5-hydroxytryptamine1A-mediated hyperpolarization in CA1 and CA3 hippocampal pyramidal cells. J Pharmacol Exp Ther. 1992;263(1):350-9.

59. Hamon M, Lanfumey L, el Mestikawy S, Boni C, Miquel MC, Bolanos F, et al. The main features of central 5-HT1 receptors. Neuropsychopharmacology. 1990:3(5-6):349-60.

60. Riad M, Garcia S, Watkins KC, Jodoin N, Doucet E, Langlois $X$, et al. Somatodendritic localization of 5-HT1A and preterminal axonal localization of 5-HT1B serotonin receptors in adult rat brain. J Comp Neurol. 2000;417(2):181-94.

61. Hjorth S, Bengtsson HJ, Kullberg A, Carlzon D, Peilot H, Auerbach SB Serotonin autoreceptor function and antidepressant drug action. J Psychopharmacol. 2000;14(2):177-85.

62. Briley M, Moret C. Neurobiological mechanisms involved in antidepressant therapies. Clin Neuropharmacol. 1993;16(5):387-400.

63. Artigas F. Serotonin receptors involved in antidepressant effects. Pharmacol Ther. 2013;137(1):119-31.

64. Lemonde S, Turecki G, Bakish D, Du L, Hrdina PD, Bown CD, et al. Impaired repression at a 5 -hydroxytryptamine $1 \mathrm{~A}$ receptor gene polymorphism associated with major depression and suicide. J Neurosci. 2003;23(25):8788-99.

65. Anttila S, Huuhka K, Huuhka M, Rontu R, Hurme M, Leinonen E, et al. Interaction between 5-HT1A and BDNF genotypes increases the risk of treatment-resistant depression. J Neural Transm (Vienna). 2007;114(8):1065-8.

66. Albert PR, Lemonde S. 5-HT1A receptors, gene repression, and depression: guilt by association. Neuroscientist. 2004;10(6):575-93.

67. Olivier JD, Valles A, van Heesch F, Afrasiab-Middelman A, Roelofs JJ, Jonkers $M$, et al. Fluoxetine administration to pregnant rats increases anxiety-related behavior in the offspring. Psychopharmacology. 2011;217(3):419-32.

68. Leung K. [(18)F]Y1-973. Molecular Imaging and Contrast Agent Database (MICAD). Bethesda (MD)2004.

69. Ortiz AA, Milardo LF, DeCarr LB, Buckholz TM, Mays MR, Claus TH, et al. A novel long-acting selective neuropeptide Y2 receptor polyethylene glycolconjugated peptide agonist reduces food intake and body weight and improves glucose metabolism in rodents. J Pharmacol Exp Ther. 2007;323(2): 692-700.

70. Paiva SP, Veloso CA, Campos FF, Carneiro MM, Tilan JU, Wang H, et al. Elevated levels of neuropeptide $Y$ in preeclampsia: a pilot study implicating a role for stress in pathogenesis of the disease. Neuropeptides. 2016;55:127-35.

71. Beloosesky R, Gayle DA, Amidi F, Ahanya SN, Desai M, Ross MG. Ontogenic expression of putative feeding peptides in the rat fetal brain and placenta. Nutr Neurosci. 2006;9(1-2):33-40.

72. Roseboom PH, Nanda SA, Fox AS, Oler JA, Shackman AJ, Shelton SE, et al. Neuropeptide $Y$ receptor gene expression in the primate amygdala predicts anxious temperament and brain metabolism. Biol Psychiatry. 2014;76(11):850-7.

73. El Marroun $H$, White T, Verhulst FC, Tiemeier H. Maternal use of antidepressant or anxiolytic medication during pregnancy and childhood neurodevelopmental outcomes: a systematic review. Eur Child Adolesc Psychiatry. 2014;23(10):973-92.

74. Lupattelli A, Spigset O, Bjornsdottir I, Hameen-Anttila K, Mardby AC, Panchaud $A$, et al. Patterns and factors associated with low adherence to psychotropic medications during pregnancy--a cross-sectional, multinational web-based study. Depress Anxiety. 2015;32(6):426-36.

75. Zoega H, Kieler H, Norgaard M, Furu K, Valdimarsdottir U, Brandt L, et al. Use of SSRI and SNRI antidepressants during pregnancy: a population-based study from Denmark, Iceland, Norway and Sweden. Plos One. 2015;10(12): e0144474.

76. Hellgren C, Edvinsson A, Olivier JD, Fornes R, Stener-Victorin E, Ubhayasekera SJ, et al. Tandem mass spectrometry determined maternal cortisone to cortisol ratio and psychiatric morbidity during pregnancyinteraction with birth weight. Psychoneuroendocrinology. 2016;69:142-9.

\section{Publisher's Note}

Springer Nature remains neutral with regard to jurisdictional claims in published maps and institutional affiliations.
Ready to submit your research? Choose BMC and benefit from:

- fast, convenient online submission

- thorough peer review by experienced researchers in your field

- rapid publication on acceptance

- support for research data, including large and complex data types

- gold Open Access which fosters wider collaboration and increased citations

- maximum visibility for your research: over $100 \mathrm{M}$ website views per year

At BMC, research is always in progress.

Learn more biomedcentral.com/submissions 